J Arid Land (2014) 6(1): 1-2

doi: $10.1007 / \mathrm{s} 40333-013-0247-\mathrm{y}$

jal.xjegi.com; www.springerlink.com/40333

\title{
Editorial: review of 2013 and expectations for 2014
}

\author{
YiBing QIAN*, JunFeng YUAN, YongSheng PENG, HaiYan ZHANG \\ Editorial Office of Journal of Arid Land, Xinjiang Institute of Ecology and Geography, Chinese Academy of Sciences, \\ Urumqi 830011, China
}

Citation: YiBing QIAN, JunFeng YUAN, YongSheng PENG, HaiYan ZHANG. 2014. Editorial: review of 2013 and expectations for 2014. Journal of Arid Land, 6(1): 1-2. doi: 10.1007/s40333-013-0247-y

The past 2013, the fifth year since the commencement of Journal of Arid Land (JAL), witnessed positive progress in all aspects of the journal. Notable achievements have been made under the joint efforts from Chinese Academy of Sciences (CAS, the superintending authority of JAL), the editorial board and the editorial staff.

In 2013, the journal was selected into the First and Second Ranking List of Scientific-Technological Journals by CAS Publication Fund, and covered by the databases of Scopus and CSCD (Chinese Science Citation Database). Partnership with Springer was also initiated in the same year, under the agreements of which Springer has exclusive distribution rights for both print and electronic versions of JAL outside Mainland China. The Springer online information platform (SpringerLink) is believed to be able to help disseminate the journal to a global audience and ultimately improve its communication among international researchers of all related fields. According to statistics from SpringerLink, monthly full-text downloads of JAL increased from a minute 12 in January to an appreciable 182 in June. Online First service, as another convenience offered by the collaboration, will significantly shorten the time lag of publication and the duration of citation latency. Compared with the previous year, the JCR (Journal Citation Reports) Impact Factor (IF) of JAL declined slightly, while the non-self-cited rate increased from a low $16 \%$ in 2011 to a high $68 \%$ in 2012 . As predicted from the current available data from Web of Science, the IF of JAL is expected to reach 0.6 or higher.
At the advent of a new year, the editorial staff of JAL would like to extend their sincerest thanks to all the peer reviewers who have either volunteered or been invited to participate as providers of valuable comments. Up to this date, we have LIU XueJun, Jiang FengQing, TANG LiSong, WEI ChangZhou, ZHANG BaiPing, ZUO XiaoAn and ZHANG YuanMing who contributed the largest number of reviews. JAL is also grateful to all its authors for publishing with it. The six largest contributors to JCR Impact Factor are as in Table 1.

In 2013, under the supportive organization of Professor NOWAK S Robert (University of Nevada, USA), JAL spared two consecutive issues for the special column of "Invasive Species and Global Change", which reported and discussed the latest developments in species invasion and global climate change in China, Central Asia, Europe, the United States, Australia and New Zealand (e.g. Radford, 2013). A considerable number of pages from the same two issues were further dedicated to the special column of "Carbon Cycle and Global Change" to present recent research advances in carbon cycle dynamics and vegetation production process under arid environments in Central Asia, primarily Northwest China (e.g. Zheng et al., 2013).

In the forthcoming 2014, JAL will continue to invite its editorial board members into the planning of columns that cover hydrology, vegetation and microorganisms under the context of aridity at regional and global scales. The year 2014 will also witness the change of JAL from a quarterly to a bimonthly

*Corresponding author: QIAN YiBing (E-mail: dt6@ms.xjb.ac.cn) 
Table 1 Six largest contributors to JCR Impact Factor (Source: Web of Knowledge, Thomson Reuters)

\begin{tabular}{|c|c|c|}
\hline & Authors and publication title & Citation total \\
\hline 1 & $\begin{array}{l}\text { Xi CHEN, JinFeng YAN, Zhi CHEN, GePing LUO, Qing SONG, WenQiang XU. 2009. A spatial geostatistical analysis } \\
\text { of impact of land use development on groundwater resources in the Sangong Oasis Region using remote sensing im- } \\
\text { agery and data. Journal of Arid Land, 1(1): 1-8. doi: 10.3724/SP.J.1227.00001 }\end{array}$ & 54 \\
\hline 2 & $\begin{array}{l}\text { YuTing FAN, YaNing CHEN, WeiHong LI, HuaiJun WANG, XinGong LI. 2011. Impacts of temperature and precipita- } \\
\text { tion on runoff in the Tarim River during the past } 50 \text { years. Journal of Arid Land, 3(3): 220-230. doi: } \\
\text { 10.3724/SP.J.1227.2011.00220 }\end{array}$ & 7 \\
\hline 3 & $\begin{array}{l}\text { ShuJuan ZHU, ZhaoFeng CHANG. 2011. Temperature and precipitation trends in Minqin Desert during the period of } \\
\text { 1961-2007. Journal of Arid Land, 3(3): 214-219. doi: 10.3724/SP.J.1227.2011.00214 }\end{array}$ & 6 \\
\hline 4 & $\begin{array}{l}\text { YiBing QIAN, HaiYan ZHANG, ZhaoNing WU, ZhongChen WANG. 2011. Vegetation composition and distribution on } \\
\text { the northern slope of Karlik Mountain to Naomaohu basin, East Tianshan Mountains. Journal of Arid Land, 3(1): } \\
\text { 15-24. doi: } 10.3724 \text { /SP.J.1227.2011.00015 }\end{array}$ & 5 \\
\hline 5 & $\begin{array}{l}\text { ShaoYong CHEN, YuanYuan SHI, YuZhen GUO, YanXiang ZHENG. 2010. Temporal and spatial variation of annual } \\
\text { mean air temperature in arid and semiarid region in northwest China over a recent } 46 \text { year period. Journal of Arid Land, } \\
\text { 2(2): } 87-97 \text {. doi: } 10.3724 / \text { SP.J.1227.2010.00087 }\end{array}$ & 5 \\
\hline 6 & $\begin{array}{l}\text { Yan LIU, DaoYuan ZHANG, HongLan YANG, MeiYing LIU, Xiang SHI. 2010. Fine-scale genetic structure of Ere- } \\
\text { mosparton songoricum and implication for conservation. Journal of Arid Land, 2(1): 26-32. doi: } \\
\text { 10.3724/SP.J.1227.2010.00026 }\end{array}$ & 5 \\
\hline
\end{tabular}

published journal. A larger volume for articles makes faster publication possible. We are here welcoming excellent researches from a broader range of authors.

JAL sticks to the optimization of its editorial board structure by admitting potential scientists. At the beginning of 2014, we had Fu BoJie (China) as a new member of the advisory board. Several others were added into the editorial board: AHMAD Sajjad (USA), GEOFFREY M Gadd (UK), HAFZULLAH Aksoy (Turkey), LIU HongYan (China), WANG GenXu (China), YANG Jian (China), YANG Tao (China), and ZHANG Chi (China).

With support from all parties, we are confident that
JAL can take a further step forward in terms of both quality and reputation. JAL wishes you a successful and prosperous 2014 and enjoyable reads. Around the world, we are looking forward to meeting you at conferences, to your next manuscripts and to any feedback you might have!

\section{References}

Radford I J. 2013. Fluctuating resources, disturbance and plant strategies: diverse mechanisms underlying plant invasions. Journal of Arid Land, 5(3): 284-297.

Zheng Y R, Jiang L H, Gao Y, et al. 2013. Persistence of four dominant psammophyte species in central Inner Mongolia of China under continual drought. Journal of Arid Land, 5(3): 331-339. 